\title{
PERHITUNGAN HARGA PREMI ASURANSI PERTANIAN YANG BERBASIS INDEKS CURAH HUJAN MENGGUNAKAN METODE BLACK SCHOLES
}

\author{
Ida Ayu Gde Khasmana Putri ${ }^{1}$, Komang Dharmawan ${ }^{2} \S$, Ni Ketut Tari Tastrawati ${ }^{3}$ \\ ${ }^{1}$ Jurusan Matematika, FMIPA - Universitas Udayana [Email: khasmanaputri@gmail.com] \\ ${ }^{2}$ Jurusan Matematika, FMIPA - Universitas Udayana [Email: k.dharmawan@unud.ac.id] \\ ${ }^{3}$ Jurusan Matematika, FMIPA - Universitas Udayana [Email: taritastrawati@yahoo.com] \\ $\S$ Corresponding Author
}

\begin{abstract}
Agricultural insurance is insurance in the agricultural sector which is relatively new introduced in Indonesia. Agricultural insurance is based on a rainfall index. It is a risk management tool that is relatively new in Indonesia. This study was purposed to determine the steps required in determining the value of the rainfall index on agricultural insurance and calculating the contract value of agricultural insurance which had to be paid on the agricultural insurance that is on rainfall indexbased by using Black-Scholes method. The result of this research are if the amount of rainfall was 130,4 mm so the amount of premium payment equals Rp. 60.694, as well as if the amount of high rainfall was 179,9 $\mathrm{mm}$ so the amount of premium payment equals Rp.902.760.
\end{abstract}

Keywords: Agricultural Insurance, Black-Scholes Method, Insurance Premium, Rainfall Index

\section{PENDAHULUAN}

Indonesia merupakan negara agraris artinya sektor pertanian memegang peranan penting dari keseluruhan perekonomian nasional (Tunjung, 2010). Peranan penting sektor pertanian di antaranya sebagai sumber pendapatan bagi masyarakat, terutama kebutuhan akan pangan, di samping itu juga sebagai investasi negara, dan membuka kesempatan kerja. Namun usaha dalam sektor pertanian mempunyai risiko tinggi yang mengakibatkan kerugian, penurunan hasil produksi yang mengakibatkan penurunan pendapatan pada petani itu sendiri. Risiko produksi yang dihadapi diakibatkan oleh berbagai faktor, salah satunya adalah curah hujan.

Curah hujan merupakan salah satu faktor yang dapat mengganggu keadaan pertanian tersebut. Keadaan curah hujan yang tidak stabil seperti menurunnya dan meningkatnya curah hujan dapat mengakibatkan hasil panen tidak bagus. Keadaan seperti ini dapat menimbulkan dampak yang besar terhadap produksi pertanian. Salah satu upaya yang dapat dilakukan untuk mengurangi risiko yang terjadi yaitu dengan memperkenalkan asuransi pertanian pada petani. Asuransi pertanian ini merupakan salah satu alternatif yang dapat membantu petani dalam menanggulangi risiko yang terjadi pada usaha pertanian (Aglina, 2015).

Asuransi merupakan suatu industri non-bank yang dapat memberikan perlindungan kepada tertanggung jika terjadi risiko pada masa yang akan datang. Asuransi pertanian adalah asuransi baru yang merupakan suatu perlindungan asuransi khusus yang dapat digunakan oleh petani dalam melindungi produksi pertanian jika terjadi gagal panen. Asuransi pertanian ini digunakan untuk mengatasi kerugian yang disebabkan oleh bencana alam, cuaca yang buruk, dan di luar kendali petani. Sehingga, asuransi ini dapat dimanfaatkan sebagai alat untuk mengurangi risiko terkait pertanian.

Menurut Wardhani \& Insyafiah (2013), dalam praktiknya banyak negara yang melakukan perlindungan bagi petani setelah petani mengalami bencana atau gagal panen. Perlindungan petani secara umum dilakukan dengan cara melindungi petani secara tradisional dan melindungi petani melalui skema asuransi 
pertanian. Melindungi petani secara tradisional dilakukan dengan cara pemerintah mengalokasikan anggaran khusus ( $a d$ hoc) untuk bencana alam di sektor pertanian. Sedangkan perlindungan petani melalui skema asuransi pertanian dilakukan dengan cara pemerintah memberikan bantuan premi asuransi kepada petani peserta asuransi. Asuransi pertanian tradisional tidak tersedia di setiap negara karena biaya asuransinya tidak layak secara ekonomi, hal ini disebabkan karena hasil dari pertanian tidak banyak dan juga perhitungan premi dapat menyulitkan pihak penanggung.

Berdasarkan kelemahan tersebut, maka akan dikenalkan asuransi baru yaitu asuransi baru yang berbasis indeks. Asuransi berbasis indeks merupakan bagian dari asuransi parametrik, dalam asuransi berbasis indeks ini pihak tertanggung akan membayar premi ketika mengalami kerugian yang dipicu oleh peristiwa alam yang dalam hal ini adalah curah hujan. Berdasarkan hal itu, penulis tertarik untuk membahas perhitungan premi asuransi berbasis indeks curah hujan menggunakan Metode BlackScholes.

Tujuan penelitian ini adalah Mengetahui langkah-langkah perhitungan premi asuransi yang berbasis indeks curah hujan menggunakan Metode Black-Scholes, dan Menghitung nilai kontrak asuransi pertanian yang harus dibayarkan pada asuransi pertanian yang berbasis indeks curah hujan dengan Metode Black-Scholes.

Asuransi menurut Kitab Undang-Undang Hukum Dagang (2016), Undang-Undang Pasal 1 Nomor 2 Tahun 1992 tentang Usaha Perasuransian menyatakan bahwa, "Asuransi adalah perjanjian antara dua pihak atau lebih di mana pihak penanggung mengikatkan diri kepada tertanggung dengan menerima premi asuransi untuk memberikan penggantian kepada tertanggung karena kerugian, kerusakan, atau kehilangan keuntungan yang diharapkan, atau tanggung jawab hukum kepada pihak ketiga yang mungkin akan diderita tertanggung yang timbul dari suatu peristiwa yang tidak pasti atau untuk memberikan suatu pembayaran yang didasarkan atas meninggal atau hidupnya seseorang yang dipertanggungkan."

Asuransi pertanian adalah suatu alternatif yang dapat digunakan oleh petani jika mengalami risiko terkait degan hasil produksi pertaniannya. Menurut Wardhani \& Insyafiah (2013), asuransi berbasis indeks dibagi menjadi tiga, yaitu asuransi berdasarkan hasil dalam suatu wilayah (area-yield insurance), Asuransi berdasarkan iklim (weather insurance) dan asuransi berbasis harga. Premi asuransi adalah sejumlah uang yang wajib dibayarkan setiap bulannya dari pihak tertanggung atas keikutsertaannya dalam asuransi.

Opsi adalah suatu kontrak yang memberikan hak (bukan kewajiban) kepada pemegang kontrak untuk membeli atau menjual suatu asset tertentu suatu perusahaan kepada penulis opsi dengan harga tertentu dalam jangka waktu tertentu. Opsi memiliki dua jenis kontrak yang sangat mendasar yaitu call option dan put option. Banyak pilihan atau cara yang dapat digunakan oleh investor dalam menentukan kontrak opsi. Berdasarkan tipe opsi dan waktunya, opsi dibedakan menjadi dua yaitu opsi tipe Eropa (European Option) dan opsi tipe Amerika (American Option).

Salah satu metode yang dapat digunakan untuk menentukan harga opsi adalah metode Black Scholes. Metode ini mulai dikembangkan oleh Fisher Black dan Myron Scholes mulai tahun 1973, dalam hal ini metode digunakan untuk menentukan nilai opsi dalam suatu kontrak harga saham. Terdapat beberapa asumsi yang digunakan metode Black-Scholes, yaitu opsi yang dijadikan acuan ialah opsi Eropa, berlaku saat waktu habis, volatilitas (variansi harga) bersifat konstan (tetap) selama usia opsi diketahui pasti, saham yang dipakai tidak dividen, serta pajak dan biaya transaksi diabaikan (Kurniawan, 2012).

Pada penelitian ini metode Black Scholes akan digunakan untuk menentukan atau menghitung premi asuransi ketika hasil produksi mengalami penurunan di bawah standar karena dipengaruhi oleh curah hujan. Menurut Okine (2014), formula tersebut dapat ditulis dalam bentuk persamaan; 


$$
\begin{aligned}
& C(S, t)=S e^{-\delta t} N\left(d_{1}\right)-K e^{-r t} N\left(d_{2}\right) \\
& P(S, t)=K e^{-r t} N\left(-d_{2}\right)-S e^{-\delta t} N\left(-d_{1}\right)
\end{aligned}
$$

dengan

$$
\begin{array}{r}
d_{1}=\frac{\ln \left(\frac{S e^{-\delta t}}{K e^{-r t}}\right)+\left(0.5 \sigma^{2}\right) t}{\sigma \sqrt{t}} \\
=\frac{\ln \left(\frac{s}{K}\right)+\left(r-\delta+0.5 \sigma^{2}\right) t}{\sigma \sqrt{t}} \\
d_{2}=\frac{\ln \left(\frac{S e^{-\delta t}}{K e^{-r t}}\right)-\left(0.5 \sigma^{2}\right) t}{\sigma \sqrt{t}} \\
=\frac{\ln \left(\frac{s}{K}\right)+\left(r-\delta-0.5 \sigma^{2}\right) t}{\sigma \sqrt{t}}
\end{array}
$$

Untuk asuransi berbasis pada indeks curah hujan, nilai pertanggungan $(P O=$ Payout $)$ bergantung pada realisasi curah hujan dan dirancang sebagai opsi put, didefinisikan sebagai;

$$
\text { Payout }=\left\{\begin{array}{rr}
K, & \text { jika } R<R_{T} \\
0, & \text { lainnya }
\end{array}\right.
$$

dengan $K$ adalah suatu harga pertanggungan asuransi terhadap petani akibat dari perubahan pada $\mathrm{CH}, \mathrm{R}_{T}$ merupakan nilai patokan yang didefinisikan sebagai rata-rata curah hujan dari bulan yang paling berkorelasi kuat terhadap hasil panen atau produksi selama delapan belas tahun. Metode lain yang dipakai untuk menghitung $P O$ adalah

$$
P O=\operatorname{maks}\left[0,\left(R-R_{T}\right)\right]
$$

Indeks premi asuransi, dengan $K$ menyatakan pembayaran pertanggungan sekaligus dapat ditulis sebagai;

$$
\text { Premi }=K e^{-r t} N\left(-d_{2}\right)
$$

\section{METODE PENELITIAN}

\section{Sumber Data}

Sumber data dalam penelitian ini menggunakan data sekunder yang diperoleh dari Dinas Pertanian Provinsi Bali dan BPS (Badan Pusat Statistika) Provinsi Bali dan Badan Meteorologi dan Geofisika Provinsi Bali. Data tersebut merupakan data caturwulan produksi padi Kota Denpasar selama delapa belas tahun mulai tahun 1998-2015 dan data curah hujan Kota Denpasar bulanan yang dirubah ke dalam bentuk caturwulan selama delapan belas tahun mulai tahun 1998-2015.

\section{Jenis Data}

Data sekunder yang didapat berupa data kuantitatif yaitu data caturwulan dari Dinas Pertanian Provinsi Bali dan Badan Pusat Statistika Provinsi Bali, dengan data berupa perkembangan produksi pertanian selama delapan belas tahun mulai tahun 1998 sampai tahun 2015 yang dapat dioperasikan.

\section{Metode Analisis}

Langkah-langkah yang digunakan dalam penelitian ini adalah:

1. Mengidentifikasi daerah atau lokasi yang akan dipakai sebagai proyek pilot dan objek penelitian: jenis tanaman, curah hujan, suhu permukaan, dan sikap petani terhadap asuransi yang akan ditawarkan.

2. Mengumpulkan data hasil panen dan data curah hujan selama delapan belas tahun, mulai tahun 1998 sampai dengan tahun 2015.

3. Memplot data curah hujan dan memplot historical produksi selama delapan belas tahun, mulai tahun 1998 sampai dengan tahun 2015.

4. Melakukan analisis regresi data historis dari curah hujan yang dirubah menjadi data caturwulan, terhadap rata-rata produksi hasil panen caturwulan selama delapan belas tahun, mulai tahun 1998 sampai dengan tahun 2015.

5. Penentuan indeks menggunakan kombinasi dari variabel curah hujan (volume curah hujan atau intensitas curah hujan) yang terukur selama delapan belas tahun yang paling representatif yang menyebabkan terjadinya risiko gagal panen.

6. Setelah data terkumpul penentuan indeks dilakukan berdasarkan caturwulan yang paling berkorelasi kuat terhadap penurunan hasil panen maka caturwulan tersebut yang dipilih dalam penentuan indeks.

7. Menentukan harga pertanggungan asuransi pertanian berdasarkan pada biaya benih padi, 
pupuk (pupuk organik dan pupuk NPK), biaya tenaga kerja dan sewa traktor.

8. Menghitung premi asuransi yang harus dibayarkan menggunakan persamaan;

$$
\text { Premi }=K e^{-r t} N\left(-d_{2}\right)
$$

\section{HASIL DAN PEMBAHASAN}

\section{Plot Data Curah Hujan}

Pada penelitian ini, langkah pertama yang dilakukan yaitu dengan memplot data curah hujan Kota Denpasar selama delapan belas tahun mulai tahun 1998 sampai dengan tahun 2015. Data curah hujan yang dipilih adalah data curah hujan bulanan Kota Denpasar selama delapan belas tahun mulai tahun 1998 sampai dengan tahun 2015. Plot data curah hujan caturwulan Kota Denpasar tahun 1998 sampai dengan tahun 2015 dapat dilihat pada gambar 1.

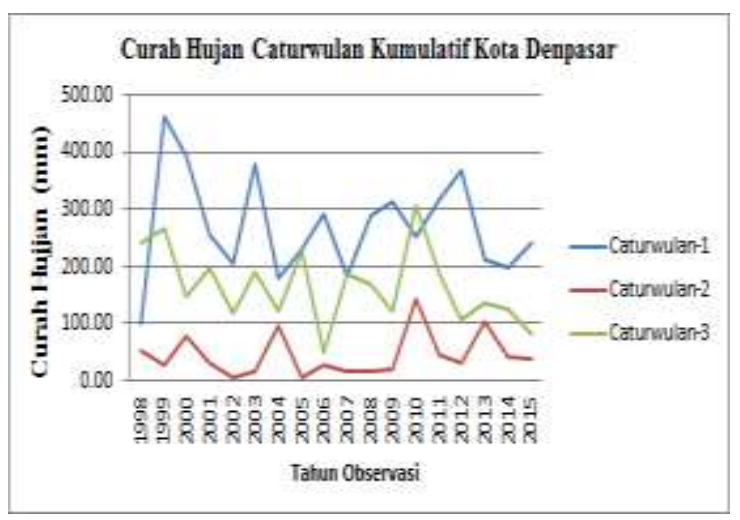

sumber: data diolah tahun 2016

Gambar 1. Plot Data Curah Hujan Caturwulan Kota Denpasar Tahun 1998-2015.

Berdasarkan plot Gambar 1 menunjukkan bahwa hasil curah hujan masing-masing caturwulan mengalami fluktuasi setiap tahunnya.

\section{Plot Data Produksi Padi}

Data hasil rata-rata produksi padi di Kota Denpasar selama delapan belas tahun mulai tahun 1998 sampai dengan tahun 2015 dilakukan dengan memplot data hasil rata-rata produksi pertanian padi Kota Denpasar selama delapan belas tahun. Plot hasil rata-rata produksi padi di Kota Denpasar dapat dilihat pada gambar 2 .

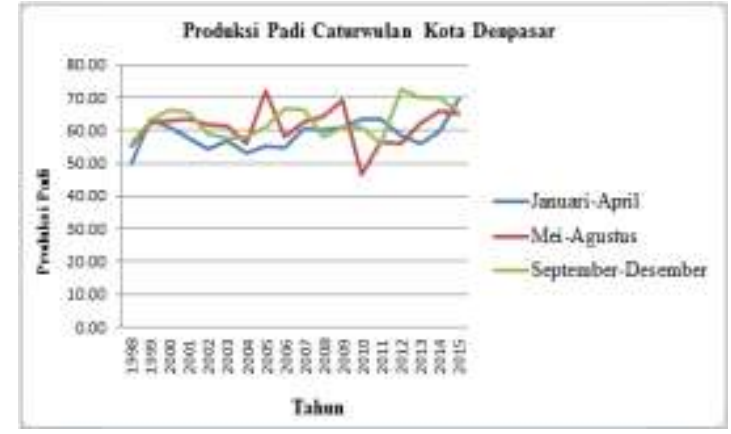

sumber: data diolah tahun 2016.

Gambar 2. Grafik Hasil Rata-Rata Produksi Padi

Kota Denpasar tahun 1998-2015

Berdasarkan plot gambar 2 dapat dilihat bahwa hsil rata-rata produksi padi mengalami fluktuasi setiap tahunnya mulai tahun 1998 sampai dengan tahun 2015.

\section{Penentuan Indeks Curah Hujan}

Penentuan indeks ini dilakukan berdasarkan caturwulan curah hujan yang paling berkorelasi kuat terhadap produksi padi. Interpretasi pada hasil ini didasarkan pada data caturwulan curah hujan dengan data produksi padi. Indeks curah hujan ini selanjutnya digunakan dalam perhitungan premi asuransi yang harus dibayarkan. Dalam perhitungan ini, hasil yang dperoleh dari analisis korelasi menggunakan bantuan Microsoft Excel 2010. Nilai Korelasi dari masing-masing caturwulan curah hujan dan produksi padi dapat dilihat pada Tabel 1 .

Tabel 1. Nilai Korelasi dari masing-masing caturwulan Curah Hujan dan Produksi Padi.

\begin{tabular}{|c|c|c|c|}
\hline PRODUKSI & \multicolumn{3}{|c|}{ CURAH HUJAN } \\
\hline & Curah Hujan 1 & Curah Hujan 2 & Curah Hujan 3 \\
\hline Caturwulan 1 & 0,44 & 0,06 & 0,05 \\
\hline Caturwulan 2 & 0,08 & $-0,64$ & $-0,27$ \\
\hline Caturwulan 3 & 0,14 & 0,07 & $-0,40$ \\
\hline
\end{tabular}

Sumber: data diolah tahun 2016

Interpretasi dari nilai korelasi terhadap ketiga caturwulan tersebut, terlihat bahwa data curah hujan yang paling berkorelasi kuat terhadap data rata-rata produksi padi yaitu data pada caturwulan satu dengan nilai sebesar 0,44. Dengan demikian caturwulan satu dipilih sebagai indeks. 


\section{Uji Kenormalan Data Curah Hujan Caturwulan Satu}

Uji kenormalan digunakan untuk mengetahui populasi data berdistribusi normal atau tidak. Dalam pembahasan ini akan digunakan uji Kolmogorov-Smirnov dengan menggunakan taraf signifikansi 0,05. Data dinyatakan berdistribusi normal jika p-value lebih besar dari $5 \%$ atau 0,05 . Hipotesis yang diajukan adalah sebagai berikut:

$H_{0}$ : Data $\mathrm{X}$ berdistribusi normal,

$H_{1}$ : Data $\mathrm{X}$ tidak berdistribusi normal.

Dalam penelitian ini data curah hujan berdistribusi lognormal. Uji ini dilakukan untuk memenuhi asumsi pada metode Black-Scholes (Okine, 2014), sehingga dapat digunakan untuk menghitung harga premi asuransi yang harus dibayarkan. Hasil perhitungan uji normalitas dihitung dengan bantuan software Minitab 2016 (Tabel 2).

Tabel 2. Hasil Uji Normalitas dengan Kolmogorov-Smirnov

\begin{tabular}{|c|c|c|c|}
\hline \multicolumn{4}{|c|}{ Uji Kenormalan Curah Hujan } \\
\hline & $\mathrm{N}$ & Std-Dev & $p$-value \\
\hline Curah Hujan & 18 & 361.8 & 0.150 \\
\hline
\end{tabular}

Tabel 2 memperlihatkan bahwa dari jumlah data sebanyak 18 data caturwulan, nilai $p$-value sebesar 0,150. $P$-value yang diperoleh lebih besar dari $\alpha=0,05$. Keputusan yang diambl adalah terima $\mathrm{H}_{0}$. Berdasarkan pada hasil tersebut, maka data curah hujan pada caturwulan satu di Kota Denpasar berditribusi normal.

\section{Penentuan Harga Pertanggungan Asuransi Pertanian}

Tahapan selanjutanya menentukan harga pertanggungan asuransi pertanian berdasarkan pada biaya input produksi padi melipti biaya benih padi, pupuk (pupuk organik dan pupuk NPK), biaya tenaga kerja, dan sewa traktor. Berdasarkan biaya input tersebut maka petani tersebut akan memperoleh nilai pertanggungan pada produksi padi sebesar Rp. 7.060.000/Ha.

\section{Penentuan Harga Premi dengan Metode Black Scholes}

Penentuan Harga Premi dengan Metode Black-Scholes.menghitung besarnya premi asuransi pertanian yang harus dibayarkan oleh petani. Dalam penentuan harga premi pada asuransi pertanian ini, akan dihitung untuk $R_{T}=$ 5 persentil $R_{T}=6$ persentil, $R_{T}=7$ persentil, $R_{T}=8$ persentil, $R_{T}=9$ persentil, $R_{T}=10$ persentil. Perhitungan persentil ini diperoleh dari indeks yang dipilih yaitu data curah hujan caturwulan satu. Berikut adalah ilustrasi perhitungan premi ketika nilai $R_{T}=10$ persentil dari 18 data, berdasarkan persamaan (6) diperoleh;

$$
\text { Premi }=K e^{-r t} N\left(-d_{2}\right)
$$

Terlebih dahulu dihitung fungsi distribusi kumulatif $d_{2}$ dengan;

$$
d_{2}=\frac{\ln \left(\frac{R_{0}}{R_{T}}\right)+\left(r-\frac{\sigma^{2}}{2}\right) t}{\sigma \sqrt{t}}
$$

Periode waktu per tahun dapat ditulis sebagai $t=0,25$, dan standar deviasi dari indeks curah hujan caturwulan satu yaitu $\sigma=0,16$, standar deviasi curah hujan caturwulan satu ini dihitung dengan bantuan software Microsoft Excel 2010.

Variabel $R_{T}$ merupakan nilai patokan yang didefiniskan sebagai rata-rata curah hujan caturwulan satu yang dipilih sebagai indeks, ketika $R_{T}=10$ persentil dari 18 data nilainya sebesar $179,9 \mathrm{~mm}$.

Dengan mengasumsikan suku bunga bebas risiko sebesar $r=6,5 \%=0,065$.

Untuk dapat menghitung premi, terlebih dahulu dihitung fungsi distribusi kumulatif $d_{2}$ saat nilai patokan curah hujan 10 persentil, yaitu sebagai berikut;

$$
\begin{aligned}
d_{2}= & \frac{\ln \left(\frac{R_{0}}{R_{T}}\right)+\left(r-\frac{\sigma^{2}}{2}\right) t}{\sigma \sqrt{t}} \\
= & \frac{n\left(\frac{239,9}{179,9}\right)+\left(0,065-\frac{(0,16)^{2}}{2}\right) \times 0,25}{0,16 \times \sqrt{0,25}}
\end{aligned}
$$




$$
\begin{gathered}
=\frac{0,303}{0.08} \\
d_{2}=3,79 \\
N\left(-d_{2}\right)=0,1321 .
\end{gathered}
$$

Berdasarkan pada hasil perhitungan fungsi distribusi kumulatif $d_{2}$ saat nilai patokan curah hujan 10 persentil yaitu sebesar 0,1321 , maka perhitungan premi yang harus dibayarkan saat nilai patokan curah hujan 10 persentil adalah sebagai berikut;

$$
\begin{aligned}
P & =K e^{-r t} N\left(-d_{2}\right) \\
& =R p 7.060 .000 \cdot e^{-0,065 \times 0,25} \times 0,1321 \\
& =R p 902.760
\end{aligned}
$$

Jadi, premi yang harus dibayarkan saat persentil ke 10 adalah sebesar Rp. 902.760. Untuk harga premi yang harus dibayarkan dengan nilai persentil yang lain dapat dilihat pada Tabel 3 .

Tabel 3. Premi yang harus dibayarkan

\begin{tabular}{|c|c|c|c|c|}
\hline $\begin{array}{c}\text { Persenti } \\
\text { Ke- }\end{array}$ & $\begin{array}{c}\text { Curah } \\
\text { Hujan } \\
(\mathrm{mm})\end{array}$ & $\begin{array}{c}\text { Harga } \\
\text { Pertanggungan } \\
(\mathrm{R} p)\end{array}$ & Premi (Rp) & $\begin{array}{c}\text { Persentase } \\
(\%)\end{array}$ \\
\hline 5 & 130,4 & 7.060 .000 & 60.694 & 0,9 \\
\hline 6 & 144,6 & 7.060 .000 & 168,140 & 2,3 \\
\hline 7 & 158,9 & 7.060 .000 & 373.710 & 5,2 \\
\hline 8 & 173,2 & 7.060 .000 & 701.350 & 9,9 \\
\hline 9 & 178,7 & 7.060 .000 & 864.010 & 12 \\
\hline 10 & 179,9 & $7,060.000$ & 902.760 & 12,5 \\
\hline
\end{tabular}

Tabel 3 menunjukkan premi yang harus dibayarkan akibat perubahan curah hujan di Kota Denpasar tahun 1998 sampai dengan tahun 2015, dapat diketahui bahwa dengan curah hujan yang semakin tinggi mengidentifikasikan pembayaran premi yang semakin besar. Terlihat bahwa ketika curah hujan sebesar 130,4 mm maka pembayaran premi sebesar Rp. 60.694, begitu pula ketika curah hujan tinggi yaitu sebesar 179,9 mm maka pembayaran premi sebesar Rp. 902.760. Curah hujan yang semakin tinggi memengaruhi peningkatan pembayaran premi yang harus dibayarkan.

\section{KESIMPULAN DAN SARAN}

\section{Kesimpulan}

Dari pembahasan yang telah dilakukan diperoleh simpulan sebagai berikut;

1. Langkah-langkah yang diperlukan dalam menentukan nilai indeks curah hujan yaitu dengan mengumpulkan data rata-rata produksi padi dan data curah hujan, memplot masing-masing data tersebut, kemudian penentuan indeks dilakukan berdasarkan caturwulan curah hujan yang paling berkorelasi kuat terhadap produksi padi. Indeks yang dipilih adalah curah hujan caturwulan satu.

2. Nilai premi yang harus dibayarkan dihitung berdasarkan indeks curah hujan yang memiliki korelasi kuat, serta perhitungan biaya input produksi padi dalam satu hektar di Kota Denpasar tahun 1998 sampai dengan tahun 2015. Curah hujan yang semakin tinggi memengaruhi peningkatan pembayaran premi yang harus dibayarkan.

\section{Saran}

Hal-hal yang dapat disarankan untuk penelitian selanjutnya adalah diharapkan dapat mencari data curah hujan dan data rata-rata produksi padi lebih banyak, serta dapat menentukan indeks dengan melibatkan suhu permukaan.

\section{DAFTAR PUSTAKA}

Aglina, U. M. (2015). Penentuan Harga Premi Asuransi Lahan Pertanian Berbassis Indeks Curah Hujan Menggunakan Pendekatan Opsi. Skripsi S1. Program Studi Statistika Jurusan Matematika Fakultas Matematika dan Ilmu Pengetahuan Alam Universitas Gadjah Mada Yogyakarta.

Kitab Undang-Undang Hukum Dagang. (2016). KITAB UNDANG-UNDANG HUKUM DAGANG (Wetboek van Koophandel voor Indonesie) S.1847-23.

KUHD_new_version.pdf.

Kurniawan, O. T. S. (2012). Penentuan Harga Opsi Saham Dengan Menggunakan Metode Beda Hingga Crank-Nicholson (C-N). $e$ - 
Journal Matematika Vol.1 No. 1 Agustus 2012, 20-24.

Okine, A. (2014). Pricing of Index Insurance Using Black Scoles Framework: A Case Study of Ghana. Master Thesis. Illinois State University.

Wardhani, I., \& Insyafiah. (2013). Kajian Persiapan Implementasi Asuransi Pertanian Secara Nasional. 13.

http://www.kemenkeu.go.id/sites/default/file s/Kajian Persiapan Implementasi Asuransi Pertanian.pdf. Diakses pada tanggal 02 Maret 2016. 